NASA Technical Memorandum 105813

$$
\begin{aligned}
& \text { NASA-TM-1258/3 } \\
& \text { Conf-920801--34 }
\end{aligned}
$$

\title{
The NASA CSTI High Capacity Power Project
}

J. Winter, J. Dudenhoefer, A. Juhasz, G. Schwarze, R. Patterson, D. Ferguson and R. Titran

National Aeronautics and Space Administration

Lewis Research Center

Cleveland, Ohio

P. Schmitz

Sverdrup Technology, Inc.

Lewis Research Center Group

Brook Park, Ohio

and

J. Vandersande

Jet Propulsion Laboratory

Pasadena, California

Prepared for the

27th Intersociety Energy Conversion Engineering Conference

cosponsored by the SAE, ACS, AIAA, ASME, IEEE, AIChE, and ANS

San Diego, California, August 3-7, 1992

\section{NASก}




\section{DISCLAIMER}

This report was prepared as an account of work sponsored by an agency of the United States Government. Neither the United States Government nor any agency Thereof, nor any of their employees, makes any warranty, express or implied, or assumes any legal liability or responsibility for the accuracy, completeness, or usefulness of any information, apparatus, product, or process disclosed, or represents that its use would not infringe privately owned rights. Reference herein to any specific commercial product, process, or service by trade name, trademark, manufacturer, or otherwise does not necessarily constitute or imply its endorsement, recommendation, or favoring by the United States Government or any agency thereof. The views and opinions of authors expressed herein do not necessarily state or reflect those of the United States Government or any agency thereof. 


\section{DISCLAIMER}

Portions of this document may be illegible in electronic image products. Images are produced from the best available original document. 


\section{THE NASA CSTI HIGH CAPACITY POWER PROJECT}

J. Winter, J. Dudenhoefer, A. Juhasz,

G. Schwarze, R. Patterson,

D. Ferguson, R. Titran

NASA Lewis Research Center

Cleveland, $\mathrm{OH}$

\author{
P. Schmitz \\ Sverdrup Technology, Inc. \\ NASA Lewis Research Center \\ Brook Park, OH
}

\author{
J. Vandersande \\ Jet Propulsion Laboratory \\ Pasadena, CA
}

\section{ABSTRACT}

The SP-100 Space Nuclear Power Program was established in 1983 by DOD, DOE, and NASA as a joint program to develop technology for military and civil applications.

Starting in 1986, NASA has funded a technology program to maintain the momentum of promising aerospace technology advancement started during Phase I of SP-100 and to strengthen, in key areas, the chances for successful development and growth capability of space nuclear reactor power systems for a wide range of future space applications.

The elements of the CSTI High Capacity Power Project include Systems Analysis, Stirling Power Conversion, Thermoelectric Power Conversion, Thermal Management, Power Management, Systems Diagnostics, Environmental Interactions, and Material/Structural Development. Technology advancement in all elements is required to provide the growth capability, high reliability and 7 to 10 year lifetime demanded for future space nuclear power systems. The overall project will develop and demonstrate the technology base required to provide a wide range of modular power systems compatible with the SP-100 reactor which facilitates operation during lunar and planetary day/night cycles as well as allowing spacecraft operation at any attitude or distance from the sun.

Significant accomplishments in all of the project elements will be presented, along with revised goals and project timelines recently developed.

\section{INTRODUCTION}

As part of the NASA, DOE and DOD SP-100 Nuclear Space Power Program, the NASA Advanced Technology Program was devised in 1986 to maintain the momentum of promising aerospace technology development and to enhance the chances for successful development and growth capability of future space nuclear reactor power systems. In 1988, the Advanced Technology Program was incorporated into NASA's new Civil Space Technology Initiative (CSTI). CSTI was a 900 million dollar, 7-year program intended to revitalize NASA's space technology by means of a focussed effort in the areas of Transportation, Operations, and Space Science. SP-100 Advanced Technology became a 65 million dollar, 7-year effort under CSTI Operations called High Capacity Power. In late 1991, an Integrated Technology Plan added two elements to CSTI -- Space Platforms and Planetary Surface Technology. Power developments for nuclear propulsion now reside under Transportation Technology and power developments for space platforms now reside under Space Platform Technology. Space Nuclear Power (SP-100) and High Capacity Power were both included in the Planetary Surface category. The overall goal was changed to developing the technology base needed to meet the long duration, high capacity power requirements for future NASA lunar and planetary surface power.

At the same time as the CSTI realignment, new funding limits were imposed and the High Capacity Power Project was redirected to eliminate refractory Stirling development, to end advanced thermoelectric development at $\mathrm{Z}=1.0 \times 10^{3} \mathrm{~K}^{-1}$, and to complete $1050 \mathrm{~K}$ Superalloy Stirling development by the end of FY94; all other elements of the project would end in FY93. Endurance testing of the Stirling converter was extended from FY95 through FY97 at a low level of funding. The funding profile for the entire project is shown in Figure 1 and the funding breakdown for the remaining years is shown in Table I.

\section{CSTI HIGH CAPACITY POWER}

The High Capacity Power Program is focussed on the development of key aerospace technology in the areas of Power Conversion, Advanced Materials, Thermal Management, Power Management, Systems Diagnostics and Environmental Interactions. Program Management is located in the Office of Aeronautics and Space Technology (OAST) at NASA Headquarters. Project Management is located at NASA Lewis Research Center in the Power Technology Division of the Aerospace Technology Directorate. The advanced thermoelectric energy conversion element is carried out at the Jet Propulsion Laboratory in Pasadena, California.

A Systems Analysis and Mission Support element is used to assess the benefits from technology advancements in all areas, and to show how new technology impacts future NASA missions. Figure 2 illustrates the revised goals of the High Capacity Power Project in terms of power and specific power available from the SP-100 reactor. More recent studies for lower temperature, lower power systems are 
summarized in Table II. The advantages of Stirling conversion compared to Brayton conversion are illustrated for a $\mathrm{UO}_{2}$ fueled reactor as well as the UN fueled SP-100 derivative reactor. Figure 3 shows the system diagram for the $\mathrm{UO}_{2}$ fueled version. Both of these systems are under consideration for power systems capable of supporting early missions such as manned lunar outposts.

The overall project roadmap is given in Figure 4. The 1050K Superalloy Stirling demonstration will be accomplished in FY92-93 at the $12.5 \mathrm{kWe} /$ cylinder size. These technology developments should, thus, be available for application to missions in the late 1990's and beyond.

\section{POWER CONVERSION}

Advanced power conversion is intended to provide significant benefits in terms of specific power and lifetime compared to state-of-the-art power systems. Advanced thermoelectrics will provide enhanced performance, ease of integration with SP-100, and inherent graceful degradation characteristics. Free piston Stirling technology will provide factors of four improvements in specific power coupled with inherent long life capability.

\section{STIRLING}

The Stirling technology development under High Capacity Power will focus on the $12.5 \mathrm{kWe}$ /cylinder, $1050 \mathrm{~K}$ superalloy Component Test Power Converter (CTPC). Figure 3 illustrates integration with a low temperature $\mathrm{UO}_{2}$ reactor cooled by $\mathrm{NaK}$ and flowing directly to the Stirling hot end heat exchanger. The converters are double-ended and each pair puts out either $10 \mathrm{kWe}$ or $40 \mathrm{kWe}$, depending upon system design requirements. The redundant converter allows $100 \%$ backup capability or the operation of both converter pairs at $50 \%$ power for a longer lifetime.

The development plan to demonstrate free-piston Stirling technology is given on Figure 5. Already accomplished is the CTPC cold end testing to $525 \mathrm{~K}$, which demonstrated heating of close tolerance parts, permanent magnet suitability at $525 \mathrm{~K}$ and self-pumped hydrostatic gas bearings for long life capability.

The next scheduled major element is the completion and integration of the hot end for the CTPC. The design incorporates heat pipe heat input to the helium working fluid and 7 year lifetime capability. The Udimet 720 alloy heater head will be used for the endurance demonstrations and the Inconel 718 heater head will demonstrate design concept feasibility and experimental correlation with lifetime predictions.

Figure 6 shows the CTPC cold end hardware ready for test. Figure 7 illustrates the hot end heater head design concept. Initial testing will use electric heaters to heat the working gas, to be followed by sodium-filled heat pipe heat input, also electrically heated.

NICKELSUPERALLOY TECHNOLOGY AND LONG LIFE - ANALYSIS/DESIGN TECHNIQUES - Research on nickel-based superalloys and metal matrix composites is being conducted in support of advanced space power systems. The objective of this research is to develop and characterize new high-temperature power conversion materials to provide space power system designers with design information and material selection options.

The following overview will discuss research on two candidate nickel based alloys. Specifically, we will cover ongoing research on the thermal stability, liquid alkali metal corrosion resistance and creep-rupture strength of IN 718 and $U \mathbf{7 2 0}$ for power conversion systems.

Proposed Stirling power conversion designs require hot section components to survive elevated temperatures of up to $1050 \mathrm{~K}$ for an operating life of 60,000 hours. With this "high temperature - long life criterion," long-term durability of these components becomes a necessity. To ensure longterm durability requires the combination of several areas of research such as a) the understanding of the temperature, displacement, and stress states of the component (finite element analysis); b) the knowledge of time-dependent (viscoplastic) and long term (thermal stability) behavior of the component's material; and finally, c) the experience of making long-term life approximations based on information from areas a) and b). All of these elements are interdependent and must be utilized throughout the design process. The High Capacity Power Project has initiated such a program that is addressing the long-term durability issues of the Stirling power converter's hot section components.

Reference material and fabrication specifications (IN 718 and $U$ 720) have been provided for the technology assessment of the joining and the liquid metal compatibility concerns for the Starfish heater head design of the Stirling Component Test Power Converter. Thermal analysis of the 1000 hour heater head design (IN 718) has been completed. The NASA finite element analysis model showed that the temperature profile of the fins which have a single row of helium gas passage holes was similar to a staggered two row fin design. The U 72060,000 hour heater head thermal analysis shows that the better fabrication technique may consist of the heater head being comprised of both a powder metal product and a thin cast wrought plate. The joining of U 720 to itself by electron beam welding has been successfully demonstrated.

\section{THERMOELECTRICS}

The Advanced T/E Development Program has concentrated on improving $\mathrm{n}$-type $\mathrm{SiGe} / \mathrm{GaP}$ by determining the optimum $\mathrm{P}$ and $\mathrm{Ga}$ concentrations and $\mathrm{P} / \mathrm{Ga}$ ratio. Theoretical models (thermodynamic and a thermal and electrical model) explain why the $\mathrm{Ga}+\mathrm{P}$ addition results in improvement (Ga-P ion pairing resulting in an increased $P$ solubility) and predicts the potential increase in $Z$ (figure of merit). Samples with various $P$ and $G a$ concentrations and $\mathrm{P} / \mathrm{Ga}$ ratios were heat treated at various high temperatures (to grow grains and increase homogeneity).

Samples with reproducible Z's between 0.85 and $0.95 \mathrm{x}$ $10^{-3} \mathrm{~K}^{-1}$ were obtained, which compares to a $Z$ for standard SiGe of $0.78 \times 10^{-3} \mathrm{~K}^{-1}$ between 600 and $1000 \mathrm{C}$. This is a reproducible improvement of $10-20$ percent. It will now be attempted to add phonon scattering centers to reduce the thermal conductivity and hence, increase $\mathrm{Z}$ to $1.0 \times 10^{-3} \mathrm{~K}^{-1}$. 
The work on improving p-type SiGe is taking place at Thermo Electron Technologies Corporation (TTC). Very fine particulates (50-100A) are being added to the p-type SiGe to reduce the thermal conductivity and increase $\mathrm{Z}$.

\section{THERMAL MANAGEMENT}

The goal of the thermal management effort is to develop space radiator concepts optimized for both static and dynamic power conversion systems using nuclear heat sources. Specific goals include $5 \mathrm{~kg} / \mathrm{m}^{2}$ specific mass, survivability up to 10 years in the micrometeoroid and space debris environment, 0.99 reliability.

Advanced radiator concept contracts are presently underway to meet these goals at $875 \mathrm{~K}$ for the thermoelectric system and at $600 \mathrm{~K}$ for the Stirling system. Rocketdyne is developing carbon-carbon composite heat pipes with integral fins and potassium compatible liners for the 875K application. Space Power Incorporated (SPI) is developing a Li/NaK pumped loop design - also with carbon-carbon fins - for the $600 \mathrm{~K}$ application. Figure 8 illustrates the Rocketdyne concept and Figure 9 illustrates the SPI concept. The contracts are presently in Phase IV subsystem testing to demonstrate engineering performance. The present schedule calls for Phase IV completion during FY93.

Space power system radiator fins require a material with high thermal conductivity, low to moderate density, and good stiffness. While some nuclear power system radiator fins operate at temperatures as low as $300 \mathrm{~K}$, most systems have fins operating at temperatures between 450 and $900 \mathrm{~K}$. $\mathrm{Gr} / \mathrm{Cu}$ composites are being considered for applications with operating temperatures above $450 \mathrm{~K}$. LeRC has shown that the specific thermal conductivity of the composite is as good or better than that of niobium, titanium, copper and beryllium. The thermal conductivity of these composites appears to follow a cosine squared law in the direction of the fiber axis. Based upon these facts, it is felt that the thermal conductivity in the plane of the radiator fin, as a function of fiber volume fraction and orientation, can be modelled and accurately predicted. The dynamic modulus of P100 graphite fiber reinforced composites was determined to be slightly over $300 \mathrm{GPa}$ up to $650 \mathrm{~K}$. The density of $\mathrm{Gr} / \mathrm{Cu}$ composites of interest range from 4.5 to $5.5 \mathrm{~g} / \mathrm{cc}$ for 60 and $40 \mathrm{vol} \%$ $\mathrm{Gr} / \mathrm{Cu}$ composites, respectively. The thermal expansion of $\mathrm{Gr} / \mathrm{Cu}$ composites can be tailored to match that of any of the proposed space heat pipe materials. The thermal expansion mismatch can be minimized since P100 graphite fibers have a small negative coefficient of thermal expansion (CTE), while copper has a much larger, positive CTE. Varying the fiber orientation and the volume fraction of the fibers leads to a CTE that minimizes the stresses in the fin to heat pipe braze joint. It has recently been shown that the CTE and any potential CTE hysteresis may be minimized with the formation of an engineered interface in the $\mathrm{Gr} / \mathrm{Cu}$ composites. By improving the bond between the graphite fibers and matrix, the strength of the composite can be improved, and any hysteresis in thermal expansion minimized or eliminated. The engineered interface has been achieved by alloying the copper matrix with chromium at approximately the $0.5 \mathrm{wt} \% \mathrm{Cr}$ level.
Space and surface nuclear power systems generally use a design guideline of 0.85 for the thermal emittance of radiator surfaces. The most efficient radiator system should be able to maintain this emittance level over its operating temperature range (700-900K for thermoelectric systems and 525-650K for Stirling engine systems). Typical materials under consideration for use as radiator fins and/or heat pipes are graphite-copper metal matrix composites and carbon-carbon composites. Both materials do not have emittance levels in the desired range as they are currently manufactured (0.32-0.38 for graphite-copper and 0.46-0.77 for carbon-carbon composites. ${ }^{1.2}$ Emittance enhancement through alteration of the material's surface morphology has been shown to be successful in increasing the thermal emittance of both of these materials. ${ }^{1.2}$

Arc texturing of graphite copper has produced thermal emittances from 0.80 to 0.94 over a temperature range of 322 to $1159 \mathrm{~K}^{1}$ Directed atomic oxygen ion beam texturing of carbon-carbon composites has likewise produced an increase in thermal emittance to levels ranging from 0.85 to 0.98 over a temperature range of 300 to $1159 \mathrm{~K}$.

Current efforts include the development of oxidation resistant coatings to protect textured surfaces from a high temperature, oxidizing environment and developing abrasion resistant textures for metal matrix composites.

\section{POWER MANAGEMENT}

The power management development work for the CSTI High Capacity Power program is presently concentrated on the following tasks: (1) Radiation and temperature effects on semiconductor power switches, (2) Temperature and frequency effects on soft magnetic materials, (3) Temperature and ageing effects on rare earth permanent magnets, and (4) Power conditioning and control for a free piston Stirling power converter. Task 1 is reported herein and the other tasks are reported elsewhere at this conference.

The objective of the semiconductor radiation-effects program is to experimentally determine and assess both the separate and combined effects of neutrons, gamma rays, and temperature on commercial, developmental and researchtype power semiconductor switches. Switches that have been or will be investigated include Bipolar Junction Transistors (BJTs), Metal-Oxide-Semiconductor Field Effect Transistors (MOSFETs), Static Induction Transistors (SITs), Insulated Gate Bipolar Transistors (IGBTs), Silicon Controlled Rectifiers (SCRs), and Metal-Oxide-Semiconductor Controlled Thyristors (MCTs). BJTs are most sensitive to neutrons which cause displacement of lattice atoms to form simple vacancy-interstitial pairs and more complex cluster defects. These defects cause a significant decrease in both the current gain $h_{\mathrm{FE}}$ and the switching storage time, and an increase in leakage currents. Figure 10 shows $h_{\mathrm{FE}}$ as a function of collector current-for pre- and post-irradiation along with post-irradiation thermal anneals for a $450 \mathrm{~V} / 50 \mathrm{~A}$ NPN BJT. The thermal annealing results indicate that the severe degradation in $h_{\mathrm{FE}}$ caused by neutrons at $300 \mathrm{~K}$ is permanent and is not reversed for thermal annealing temperatures up to $425 \mathrm{~K}$. MOSFETs, as shown in 
Figure 11, are most sensitive to gamma rays (ionization process) which cause shifts in the gate-source threshold voltage due to positive charge build-up in the gate oxide and the formation of interface states. SITs are found to be neither sensitive to neutrons or gamma rays for neutron fluences to $10^{13} \mathrm{n} / \mathrm{cm}^{2}$ and gamma doses to $0.5 \mathrm{Mrads}$, respectively. For fluences beyond $10^{13} \mathrm{n} / \mathrm{cm}^{2}$, the drainsource on resistance $R_{D S(o n)}$ begins to show a significant increase, but no significant increase was observed in $R_{\mathrm{DS}(\mathrm{on})}$ for gamma doses up to 1.8 Mrads. Reference 3 gives a comprehensive discussion of the effects of neutrons, gamma rays, and post-irradiation thermal annealing on BJTs, MOSFETs, and SITs. The effects of neutrons, gamma rays, and temperature on the electrical and switching characteristics on both phase-control and inverter-type SCRs will be presented at this conference (4).

\section{SYSTEMS DIAGNOSTICS}

For the past three years, NASA Lewis has been working with the National Institute of Standards and Technology at Boulder, Colorado, to develop fiber-optic electrical current and voltage sensors which will operate in aerospace environments. Fiber optic sensor advantages include high sensitivity, immunity to EMI and RFI interference, low mass, small size, remote measurement capability and elimination of ground loop problems. While there were early problems with low temperature operation for the current sensor, the most recent current sensor gives strong indications that it will function over the entire specified range of -65 to 125 degrees Celsius. Temperature tests and vibration tests (to $20 \mathrm{~g}$ ) are in progress. Earlier tests on fiber-optic voltage sensors showed that voltage sensors manufactured with multimode (larger diameter) fibers were much too sensitive to mechanical vibration. Multimode sensors were much easier to fabricate than sensors made up of single mode fibers. At present, concentration is on voltage sensors using single mode fibers in order to overcome the vibration sensitivity problem.

NASA Lewis, NIST, the Navy's David Taylor Labs, and 3M Corporation received an R\&D 100 award in late 1991 for development of the fiber-optic current sensor.

\section{ENVIRONMENTAL INTERACTIONS}

The CSTI High Capacity Power Environmental Interactions Program has made great progress in defining and evaluating the interactions of the SP-100 power system with its expected ambient environments. The NASCAP/LEO and POLAR computer codes have shown that local electric fields at the User Interface Module will be high. Particular attention must be paid to geometries and materials in this region, to prevent arcing at conductorinsulator junctions in LEO.

NASCAP/LEO and EPSAT computer models showed that SP-100 payloads will float about 100 volts negative of the LEO plasma. Ground tests and modeling done for the Space Station Freedom Electrical Grounding Tiger Team effort found that dielectric coatings often break down at such voltages in a plasma. Thus, care must be used in selecting surface coatings for SP-100 payloads. Sputtering may also be a concern for long duration missions in LEO at such voltages. Much work has been done on a sputtering model to help evaluate surface material loss rates on SP-100 payloads in LEO.

Parasitic power losses due to plasma current collected from possible pinholes or coating defects have been quantified and shown to be small in ground plasma chamber testing of cables and cable insulators at SP-100 voltages. Modeling has shown the power loss from currents to other surfaces is also small.

Atomic oxygen durability of SP-100 materials and coatings continues to be investigated in ground tests and the upcoming EOIM-3 Shuttle flight experiment. EOIM-3, which will evaluate a host of SP-100 materials for atomic oxygen durability in LEO, is ready for launch later this year.

Finally, evaluation of the interactions of the SP-100 power system with lunar and planetary environments has started. A Workshop on Chemical and Electrical Interactions on Mars was recently held at NASA LeRC, and many of the primary interactions were identified. In Low Mars Orbit, many of the concerns now being addressed for LEO will be important, and the present Environmental Interactions Program will be very relevant. On the surfaces of the moon and Mars, new issues arise. A workshop report is now in publication.

\section{REFERENCES}

1. Rutledge, S. K.; Forkapa, M. J.; and Cooper, J. M.: "Thermal Emittance Enhancement of Graphite-Cooper Composites for High Temperature Space Based Radiators," prepared for the conference on Advanced Space Exploration Initiative Technologies (AIAA, NASA, OAI), Cleveland, OH, September 4-6, 1991. ALAA-91-3527.

2. Rutledge, S. K.; Hotes, D. H.; and Paulsen, P. E.: "The Effects of Atomic Oxygen on the Thermal Emittance of High Temperature Radiator Surfaces," prepared for the Spring Meeting of the Materials Research Society, San Diego, CA, April 24-29, 1989. NASA TM 103224.

3. Schwarze, G. E., and Frasca, A. J.: "Neutron, Gamma Ray and Post-Irradiation Thermal Annealing Effects on Power Semiconductor Switches," AIAA/NASA/OAI Conference on Advanced SEI Technologies, September 4-6, 1991, Cleveland, OH. ALAA paper 91-3525.

4. Frasca, A. J.; Schwarze, G. E.: "Neutron, Gamma Ray and Temperature Effects on the Electrical Characteristics of Thyristors," in Procedures of the 27th Intersociety Enengy Conversion Engineering Conference, held in San Diego, CA, August 3-7, 1992. 
TABLE 1 CSTI High Capacity Power Funding Estimate - \$k TO LeRC (6/17/92)

\begin{tabular}{|c|c|c|c|c|c|c|c|c|}
\hline ELE. & $\begin{array}{l}\text { PROGRAM } \\
\text { ELEMENT }\end{array}$ & FY91 & FYen & FYos & FYOA & FYes & FYos & FY97 \\
\hline 11 & $\begin{array}{l}\text { Conv Sys for Nudiear } \\
\text { Application } \\
11-1 \text { String }\end{array}$ & 5728 & 7337 & 2486 & 2160 & 720 & 720 & 720 \\
\hline 21 & Thermed Management & 1391 & 1566 & 500 & -1 & - & $\cdot$ & - \\
\hline 31 & Power Management & 100 & 130 & 25 &. & - & - & $\cdot$ \\
\hline 41 & Systems Diagnostces & 100 & 100 & 25 & -1 & $\cdot$ & $\cdot$ & - \\
\hline 51 & Envronmentad Interactions & 54 & 164 & 25 &. & - & - & \\
\hline & $\begin{array}{l}\text { Total Net R\&D } \\
\text { Program Support }\end{array}$ & $\begin{array}{l}7371 \\
2280\end{array}$ & $\begin{array}{l}9287 \\
1155\end{array}$ & $\begin{array}{c}3061 \\
947\end{array}$ & $\begin{array}{r}2160 \\
540\end{array}$ & $\begin{array}{l}720 \\
180\end{array}$ & $\begin{array}{l}720 \\
180\end{array}$ & $\begin{array}{l}720 \\
180\end{array}$ \\
\hline & Total & 8651 & 10452 & 4008 & 2700 & 800 & $\mathbf{9 0 0}$ & 800 \\
\hline
\end{tabular}

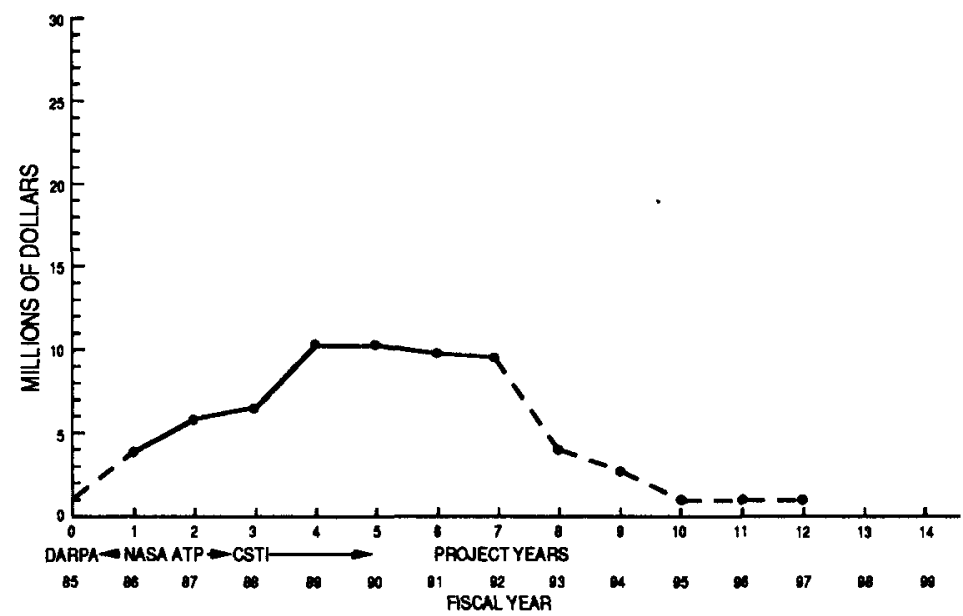

FGURE 1 Gross Funding History/Projactions NASA SP.100 ATP - High Capacity Power
TABLE 2

\begin{tabular}{|c|c|c|c|c|c|c|}
\hline & \multicolumn{2}{|c|}{$\begin{array}{l}10 \mathrm{kWe} \\
1 \text { year life }\end{array}$} & \multicolumn{2}{|c|}{$\begin{array}{c}40 \mathrm{kWe} \\
1 \text { year life }\end{array}$} & \multicolumn{2}{|c|}{$\begin{array}{c}40 \mathrm{kWe} \\
1 \text { year life }\end{array}$} \\
\hline Reactor & \multicolumn{2}{|c|}{$\begin{array}{l}\text { UCR Fuel } \\
\text { Stanless Steel } \\
\text { NaK Coolart } \\
\text { 950K Outlet Temp }\end{array}$} & \multicolumn{2}{|c|}{$\begin{array}{c}\text { UO2 Fud } \\
\text { Stainless Stod } \\
\text { NaK Coolant } \\
\text { 950K Oulet Temp }\end{array}$} & \multicolumn{2}{|c|}{$\begin{array}{c}\text { UN Fuel } \\
\text { Nb-1Z } \\
\text { U Coolant } \\
\text { 1350K Oulet Temp }\end{array}$} \\
\hline Shield & \multicolumn{2}{|c|}{$\begin{array}{c}20 \mathrm{~m} \text { Boom Length } \\
45 \mathrm{~m} \text { Payioad Dia } \\
1013 \mathrm{~mm} \\
505 \mathrm{rad}\end{array}$} & \multicolumn{2}{|c|}{$\begin{array}{c}20 \mathrm{~m} \text { Boom Length } \\
45 \mathrm{~m} \text { Payload Dia } \\
1013 \mathrm{~nm} \\
565 \mathrm{rad}\end{array}$} & \multicolumn{2}{|c|}{$\begin{array}{c}20 \mathrm{~m} \text { Boom Length } \\
4.5 \mathrm{~m} \text { Payload Dia } \\
1013 \mathrm{~mm} \\
505 \mathrm{rad}\end{array}$} \\
\hline Power Conversion (1) & $\begin{array}{l}\text { CBC } \\
\text { hconed } \\
940 \mathrm{~K} \text { TIT } \\
100 \% \text { red }\end{array}$ & $\begin{array}{l}\text { FPSE } \\
\text { Inconel } \\
950 \mathrm{~K} \text { Th } \\
100 \% \mathrm{red}\end{array}$ & $\begin{array}{l}\text { CBC } \\
\text { Inconed } \\
940 \mathrm{~K} \text { TIT } \\
100 \% \text { red }\end{array}$ & $\begin{array}{l}\text { FPSE } \\
\text { Inconel } \\
950 \mathrm{~K} \text { Th } \\
100 \% \text { red }\end{array}$ & $\begin{array}{c}\text { CBC } \\
\text { Inconel } \\
1144 \mathrm{~K} \text { TIT } \\
100 \% \text { red }\end{array}$ & $\begin{array}{l}\text { FPSE } \\
\text { Inconel } \\
1050 \mathrm{~K} \text { Jh } \\
100 \% \mathrm{red}\end{array}$ \\
\hline Heat Rejection & \multicolumn{2}{|c|}{$\begin{array}{c}\mathrm{H}_{2} \mathrm{O} \text { Cu Heat Pipes } \\
\text { Amored/Survable } \\
10 \% \text { Redundancy } \\
675 \mathrm{~kg}^{2} \mathrm{~m}^{2}\end{array}$} & \multicolumn{2}{|c|}{$\begin{array}{c}\mathrm{H}_{2} \mathrm{OCu} \text { Heat Pipes } \\
\text { AmmoredSurvwable } \\
10 \% \text { Redundancy } \\
675 \mathrm{~kg} / \mathrm{m}^{2}\end{array}$} & \multicolumn{2}{|c|}{$\begin{array}{c}\mathrm{H}_{2} \mathrm{OCu} \text { Heat Pipes } \\
\text { Amored Survwable } \\
10 \% \text { Redundancy } \\
675 \mathrm{~kg}^{2} \mathrm{~m}^{2}\end{array}$} \\
\hline System Mass (kg) & 1641 & 1191 & 3326 & 2213 & 2605 & 2004 \\
\hline Radiator Area $\left(m^{2}\right)$ & 40 & 21 & 117 & 85 & 90 & 43 \\
\hline
\end{tabular}

(1) CBC conversion based on NASA BRU engine, FPSE conversion based on NASA CTP C engne
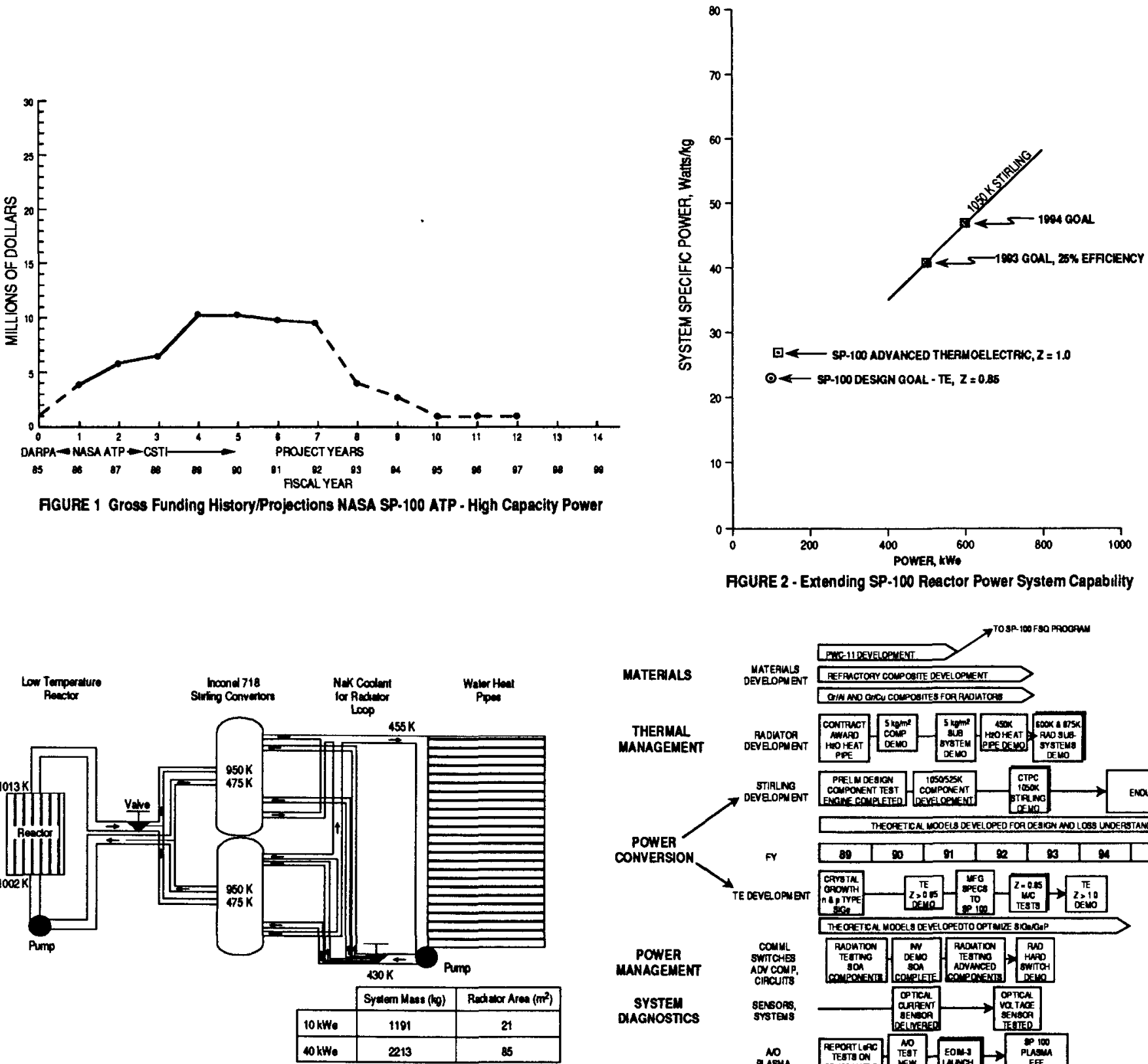

FIGURE $310 \& 40 \mathrm{kWe}$ Super Alloy Reactor/Stiling Power System
ATERALS

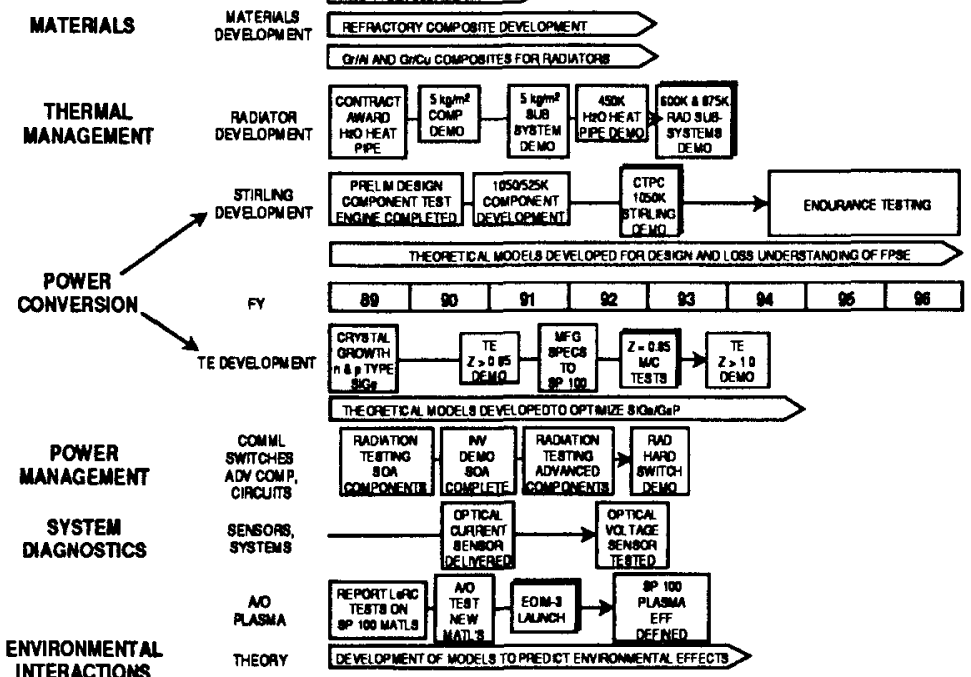

FIGURE 4 - High Capacity Power Project Schedule 


\section{COMPONENT TEST POWER CONVERTER (CTPC)}

COLD END MOTORING TEST

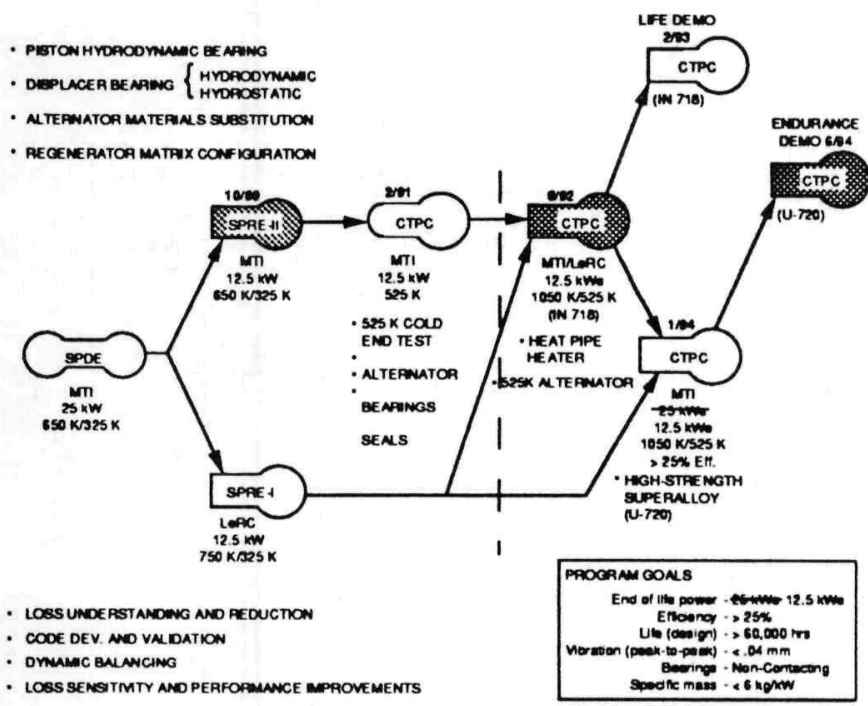

FIGURE 5 Stirling Development
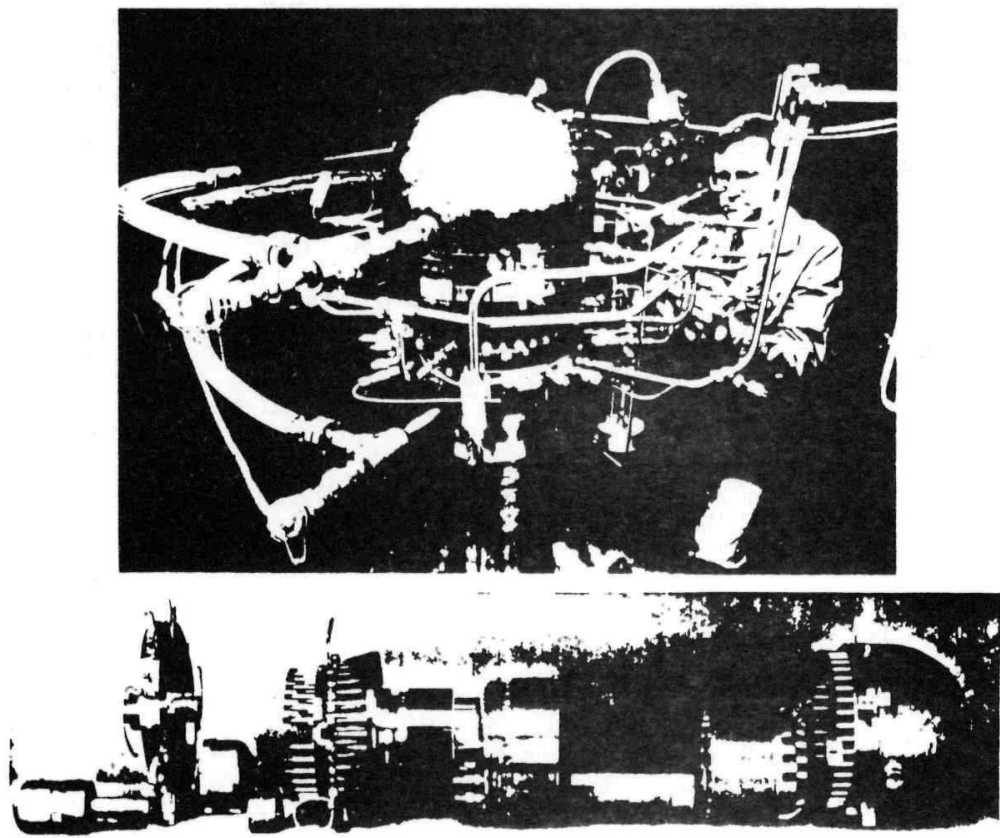

FIGURE 6
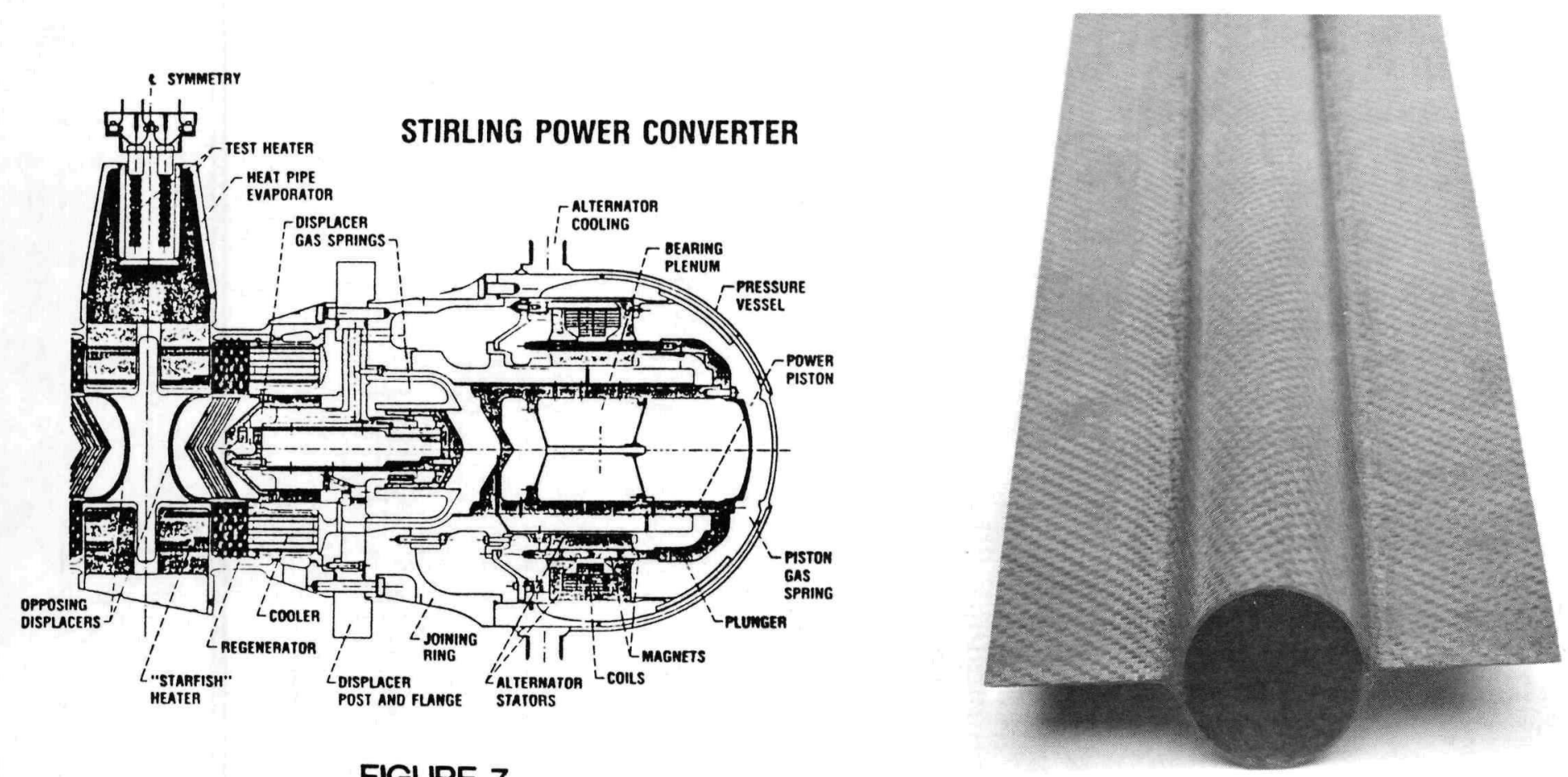

FIGURE 7

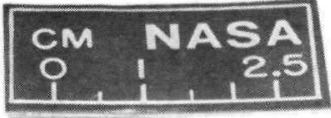




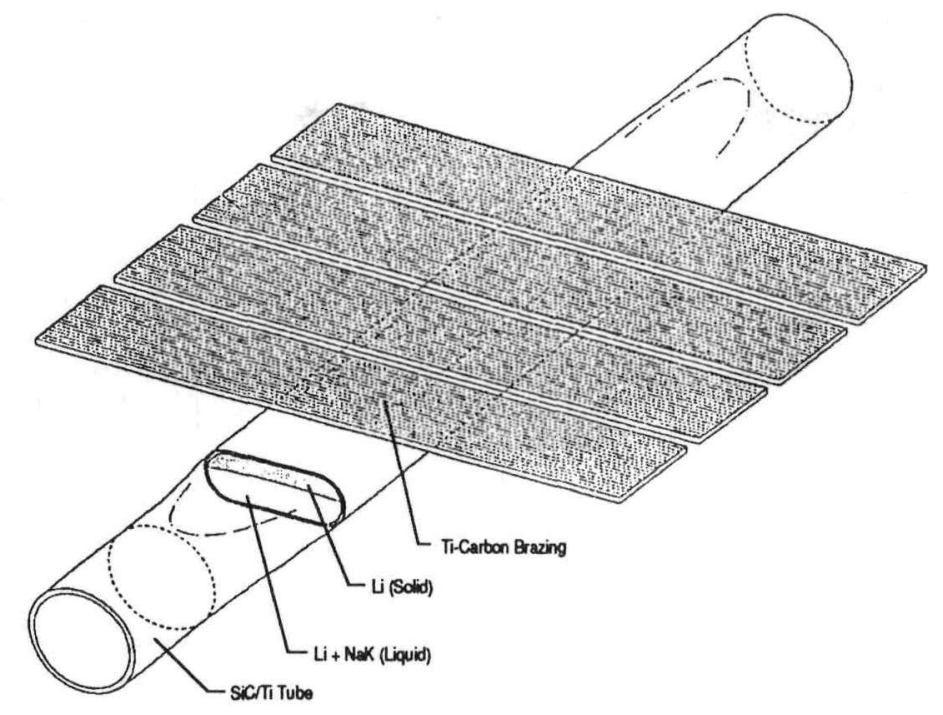

FIGURE9 Low Temperature LiNaK Radiator Experimental Test Section Operated in Li-NaK Loop

DC CURRENT GAIN @ V VE $=2.5$ V VERSUS COLLECTOR CURRENT FOR PRE-IRRADIATION, POST-IRRADIATION (FLUX $=7.55 \times 10^{8} \mathrm{n} / \mathrm{cm}^{2} \mathrm{~s}$, FLUENCE $=1.65 \times 10^{13} \mathrm{n} / \mathrm{cm}^{2}$, GAMMA DOSE $=37 \mathrm{krads}$ ), AND THERMAL ANNEALING CONDITIONS FOR NPN TRANSISTOR D60T455010. ALL MEASUREMENTS MADE AT $300 \mathrm{~K}$.

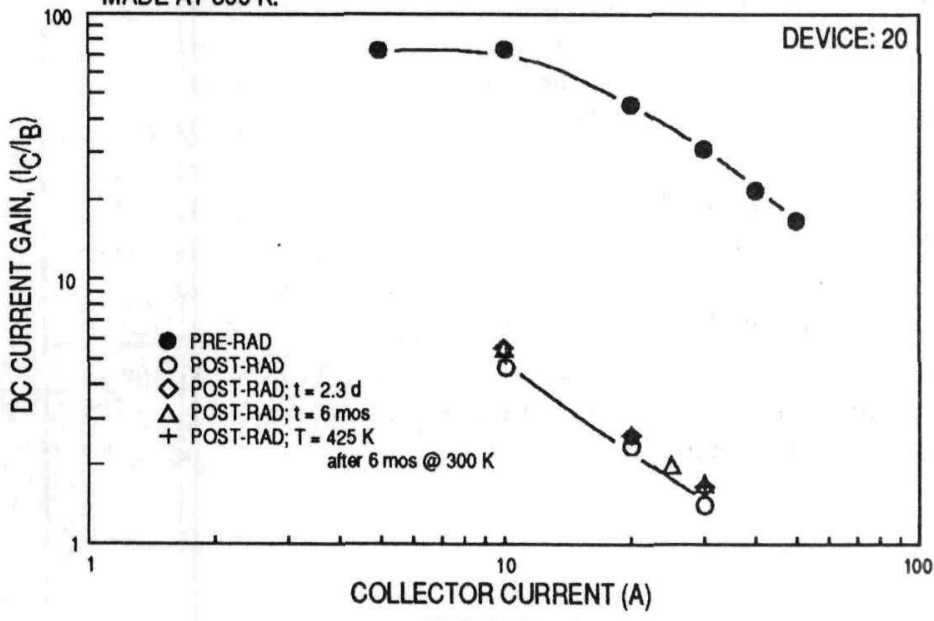

FIGURE 10
GATE-SOURCE THRESHOLD VOLTAGE VERSUS GAMMA DOSE FOR N-CHANNEL MTM15N50 (500V/15 A); GAMMA DOSE RATE = 33.8 TO $62.1 \mathrm{krads} / \mathrm{hr}$.

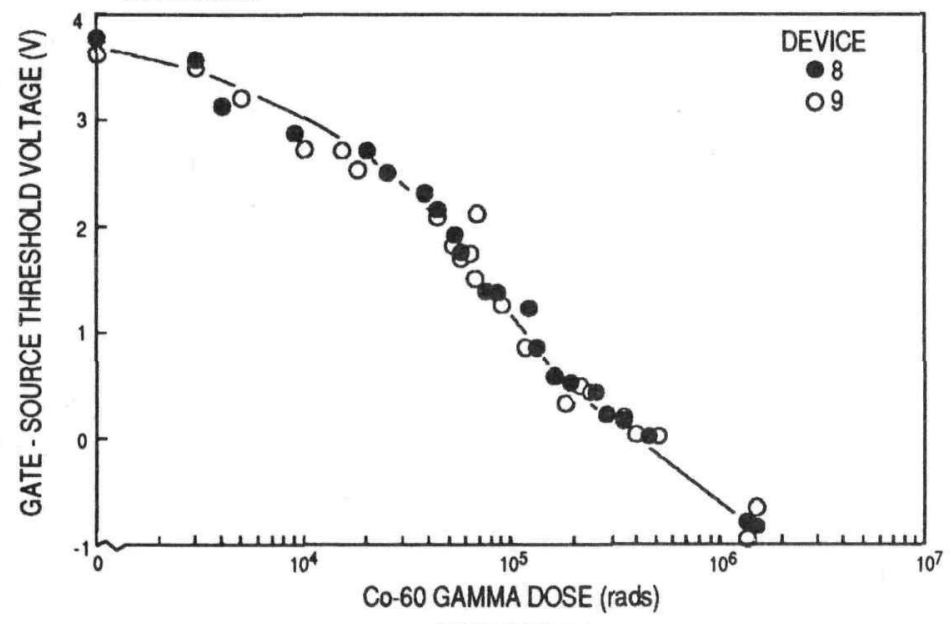

FIGURE 11 
Public reporting burden for this collection of information is estimated to average 1 hour per response, including the time for reviewing instructions, searching existing data sources, gathering and maintaining the data needed, and completing and reviewing the collection of information Send comments regarding this burden estimate or any other aspect of this collection of information, including suggestions for reducing this burden, to Washington Headquarters Services, Directorate for information Operations and Reports, 1215 Jefferson Davis Highway, Sulte 1204, Arlington, VA 22202-4302, and to the Office of Management and Budget, Paperwork Reduction Project (0704-0188), Washington, DC 20503

\begin{tabular}{|l|l|l|}
\hline 1. AGENCY USE ONLY (Leave blank) & 2. REPORT DATE & 3. REPORT TYPE AND DATES COVERED
\end{tabular}

\begin{tabular}{|l|r|r|}
\hline August 1992 & Technical Memorandum \\
\hline
\end{tabular}

4. TITLE AND SUBTITLE

The NASA CSTI High Capacity Power Project
5. FUNDING NUMBERS

WU-590-13

\section{AUTHOR(S)}

J. Winter, J. Dudenhoefer, A. Juhasz, G. Schwarze, R. Patterson, D. Ferguson, R. Titran, P. Schmitz, and J. Vandersande

\section{PERFORMING ORgANIZATION NAME(S) AND ADDRESS(ES)}

National Aeronautics and Space Administration

Lewis Research Center

Cleveland, Ohio 44135-3191

8. PERFORMING ORGANIZATION REPORT NUMBER

$\mathrm{E}-7244$

9. SPONSORING/MONITORING AGENCY NAMES(S) AND ADDRESS(ES)

10. SPONSORING/MONITORING AGENCY REPORT NUMBER

National Aeronautics and Space Administration

Washington, D.C. 20546-0001

NASA TM-105813

\section{SUPPLEMENTARY NOTES}

Prepared for the 27th Intersociety Energy Conversion Engineering Conference cosponsored by the SAE, ACS, AIAA, ASME, IEEE, AIChE, and ANS San Diego, California, August 3-7, 1992. J. Winter, J. Dudenhoefer, A. Juhasz, G. Schwarze, R. Patterson, and D. Ferguson, NASA Lewis Research Center, Cleveland, Ohio. P. Schmitz, Sverdrup Technology, Inc., Lewis Research Center Group, 2001 Aerospace Parkway, Brook Park, Ohio, 44142. J. Vandersande, Jet Propulsion Laboratory, Pasadena, California 91109. Responsible person, J. Winter, (216) 433-6133.

12a. DISTRIBUTION/AVAILABILITY STATEMENT 12b. DISTRIBUTION CODE

Unclassified - Unlimited

Subject Category 14

\section{ABSTRACT (Maximum 200 words)}

The SP-100 Space Nuclear Power Program was established in 1983 by DOD, DOE, and NASA as a joint program to develop technology for military and civil applications. Starting in 1986, NASA has funded a technology program to maintain the momentum of promising aerospace technology advancement started during Phase I of SP-100 and to strengthen, in key areas, the chances for successful development and growth capability of space nuclear reactor power systems for a wide range of future space applications. The elements of the CSTI High Capacity Power Project include Systems Analysis, Stirling Power Conversion, Thermoelectric Power Conversion, Thermal Management, Power Management, Systems Diagnostics, Environmental Interactions, and Material/Structural Development. Technology advancement in all elements is required to provide the growth capability, high reliability and 7 to 10 year lifetime demanded for future space nuclear power systems. The overall project will develop and demonstrate the technology base required to provide a wide range of modular power systems compatible with the SP-100 reactor which facilitates operation during lunar and planetary day/night cycles as well as allowing spacecraft operation at any attitude or distance from the sun. Significant accomplishments in all of the project elements will be presented, along with revised goals and project timelines recently developed.

14. SUBJECT TERMS
Stirling; Thermoelectric; Superalloys; Composites; Radiators

\begin{tabular}{|c|c|}
\hline $\begin{array}{c}\text { 17. SECURITY CLASSIFICATION } \\
\text { OF REPORT } \\
\text { Unclassified }\end{array}$ & $\begin{array}{c}\text { 18. SECURITY CLASSIFICATION } \\
\text { OF THIS PAGE } \\
\text { Unclassified }\end{array}$ \\
\hline
\end{tabular}
19. SECURITY CLASSIFICATION OF ABSTRACT Unclassified 
National Aeronautics and Space Administration

Lewis Research Conter

Cleveland, Ohio 44135

Otiliolel Buetnece.

Pondity for Privale Une $\$ 3300$

FOURTH CLASS MAIL

ADDRESS CORRECTION REQUESTED

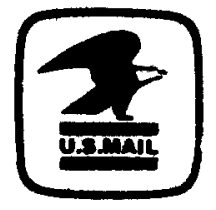

Postage and Fees Paid

National Aeronaulics and

Space Administration

NASA 451 